\title{
A new species and a new record of Diatrypaceae from Iran
}

\author{
Mehrabi $\mathbf{M}^{1}$, Hemmati $\mathbf{R}^{1}$, Vasilyeva $L \mathbf{N}^{2}$ and Trouillas $\mathbf{F P}^{3}$ \\ ${ }^{1}$ Department of Plant Protection, Faculty of Agriculture, University of Zanjan, Iran \\ ${ }^{2}$ Institute of Biology \& Soil Science, Far East Branch of the Russian Academy of Sciences, Vladivostok 690022, Russia \\ ${ }^{3}$ Department of Plant Pathology, University of California, Davis, CA 95616, USA
}

Mehrabi M, Hemmati R, Vasilyeva LN, Trouillas FP 2015 - A new species and a new record of Diatrypaceae from Iran. Mycosphere 6(1), 60-68, Doi 10.5943/mycosphere/6/1/7

\begin{abstract}
Two species of Diatrypaceae (Xylariales) are described and illustrate from Iran. Diatrypella iranensis from dead branches of Quercus brantii is described as a new species based on both morphology and molecular sequence data. It differs from other members of the genus on the basis of stroma morphology and ascus and ascospore sizes. Molecular data of the ITS rDNA region show that the new species is a sister taxon of Diatrypella quercina. Cryptovalsa ampelina is described from dead branches of Juglans regia and is a new record from Iran. This study is the first in a series that investigate the diversity of Diatrypaceae from Iran.
\end{abstract}

Key word - Cryptovalsa - Diatrypella - Iran - Taxonomy

\section{Introduction}

According to the Dictionnary of fungi (Kirk et al. 2008), the Diatrypaceae is a family of the Xylariales order within the Ascomycota phylum. The family contains 13 genera and 229 species and the most common diatrypaceous genera consist of Cryptosphaeria Ces. \& De Not. Cryptovalsa (Ces. \& De Not.), Diatrype Fr., Diatrypella (Ces. \& De Not.) De Not., Eutypa Tul. \& C. Tul., and Eutypella (Nitschke) Sacc. Morphologically, the member of Diatrypaceae are characterized by perithecial ascomata, long stalked asci and allantoid ascospores (Glawe \& Rogers 1984).

Several species in this family have been shown to cause plant diseases. Eutypa lata (Pers.) Tul. \& C. Tul. (syn: E. armeniacae Hansf. \& Carter), the causal agent of Eutypa dieback, is the best known plant pathogen in this family. This fungus has a cosmopolitan distribution and occurs on many woody plant species including cultivated plants such as grapevine, apricots and cherries (Carter 1991, Trouillas \& Gubler 2004). Other diatrypaceous taxa, such as Cryptosphaeria lignyota (Fr.) Auersw. (Hinds 1981), Cryptosphaeria pullmanensis Glawe (Trouillas \& Gubler 2010), Cryptovalsa ampelina (Nitschke) Fuckel (Mostert et al. 2004, Luque et al. 2006, Martín et al. 2009, Trouillas \& Gubler, 2010), Eutypa leptoplaca (Mont.) Rappaz (Trouillas \& Gubler 2004, 2010), Eutypella parasitica R.W. Davidson \& R.C. Lorenz (Davidson \& Lorenz 1938) and Eutypella vitis (Schwein.) Ellis \& Everh. (Catal et al. 2007, Jordan \& Schilder 2007, Úrbez-Torres et al. 2009, 2011) also were shown to cause canker diseases and wood decay in various woody plants.

A recent review on Diatrypaceae was provided by Trouillas et al. (2011). Additionnal detailed reviews on the taxonomy of the family and the generic concepts are given by Tiffany \& Gilman (1965), Glawe \& Rogers (1984), Rappaz (1987), Vasilyeva \& Stephenson $(2004,2005)$ and Carmarán et al. (2006). Rappaz (1987) revised the taxonomy of octosporous diatrypaceous fungi 
and eight genera were recognized. Glawe \& Rogers (1984) and Tiffany \& Gilman (1965) studied this family in North America and reported various species of the Diatrypaceae in this area. Vasilyeva \& Stephenson $(2004,2005,2006,2009)$ described various species of the Diatrypaceae from the Great Smoky Mountains National Park in the eastern United States, as well as Arkansas and Texas. Acero et al. (2004) presented the first phylogenetic classification of these fungi based on ITS rDNA sequence data. Parsimony analysis established the existence of nine phylogenetic groups and none of the five main diatrypaceaous genera including Cryptosphaeria, Diatrype, Diatrypella, Eutypa and Eutypella were found to be monophyletic. Also, the phylogenetic relationships also did not correlate well with classical taxonomic schemes. Romero \& Carmarán (2003) and Carmarán et al. (2009) provided new records as well as new species of the Diatrypaceae from Argentina. Grassi et al. (2014) investigated the extracellular production of ligninolytic enzymes by xylariaceous and diatrypaceous species from Argentina and described a new species of Eutypa genus. Trouillas \& Gubler (2004) and Trouillas et al. (2010a,b, 2011) also reported and described many other diatrypaceous species occurring on Vitis vinifera and other woody plants in California and Australia based on both morphological studies and DNA sequence analyses. In Panama, Chacón et al. (2013) reported and described a new species and a new record of the Diatrypaceae. In north-eastern China, Vasilyeva \& Ma (2014) described 13 species belonging to the genera Diatrype and Cryptosphaeria.

There are few publications on the Diatrypaceae from Iran. Records of fungal species known in Iran have been compiled by Ershad (2009) who listed 4 species in the third edition of "Fungi of Iran". These included Cryptovalsa mori (Nitschke) Lar. N. Vassiljeva, Diatrype stigma (Hoffm.) Fr., Eutypa lata and Eutypella iranica Petr. Occurrence of anamorphic states of this family in Iran was reported by Mehrabi \& Hemmati (2012). Overall, little information is available on the occurrence and diversity of Diatrypaceae in Iran. This study is the first in a series to investigate the diversity of the Diatrypaceae in Iran using morphological and molecular data.

\section{Materials \& methods}

\section{Fungal isolates}

During April and May 2013, two diatrypaceous species were collected on dead branches of Quercus brantii Lindl. and Juglans regia L. from Iran. Isolates were grown from a single ascospore using the method of Trouillas et al. (2010a). Dry specimens were deposited in the herbarium of Iranian Research Institute of Plant Protection (IRAN...F), and fresh cultures were deposited at the Iranian Fungal Culture Collection (IRAN...C) at the same institute.

\section{Identification and morphological studies}

To identify the diatrypaceous species collected in this study, we compared the morphology of our specimens with the descriptions of Glawe \& Rogers (1984), Croxall (1950), Vasilyeva \& Stephenson (2005) and Trouillas et al. (2010a). Identifications of species were based on morphological features of the sexual morph fruiting bodies produced on infected plant tissues. For this purpose, thin cross sections were prepared by hand from fruiting bodies. Morphological features of sexual morph such as size of stromata, size and number of perithecia, presence or absence of black zone, size of asci and asccospores, were used for the identification of fungi. Microscopic analyses and photography were conducted using standard light microscopy with a Nikon 80i microscope and a Canon digital camera. Stromal and perithecial characteristics were examined using an Olympus (SZH) stereo microscope. Examinations and measurements of microscopic characters were carried out in water. Thirty ascospores, twenty asci and thirty perithecia of each species isolate were measured.

\section{DNA extraction and sequencing}

Isolates were obtained from single ascospore and pure cultures were grown on potatodextrose agar at $25^{\circ} \mathrm{C}$. To proceed with DNA extraction, isolates were grown in liquid cultures of potato dextrose broth for 7-14 days at $25 \mathrm{C}$ on a shaker at $120 \mathrm{rpm}$. Mycelia were then vacuum 
filtered and subsequently stored at $-20^{\circ} \mathrm{C}$. Genomic DNA for PCR was isolated by method of Liu et al. (2000). Sequences of the nuclear internal transcribed spacer (ITS) region of the ribosomal DNA (rDNA) were obtained following amplification by polymerase chain reaction (PCR) using primers ITS1 and ITS4 (White et al. 1990). All reactions were performed on a PC-320 PCR System (ASTEC Co., Japan), following the temperature profiles described in Stewart et al. (2006) for the ITS region. The PCR products were purified and sent out for sequencing in both directions (Macrogen company, South Korea).

\section{Sequencing alignment and phylogenetic analysis}

The newly obtained nucleotide sequences were proofread and edited with FinchTV v. 1.4.0 (Geospiza Inc.). The sequences obtained were compared with those in the GenBank databases using the BLAST program. Sequences retrieved from GenBank and those in this study were consequently manually aligned in the program Molecular Evolutionary Genetic Analysis (MEGA) v5 (Tamura et al. 2011). DNA sequences were aligned with Clustal W (Thompson et al. 1994), within the MEGA5. Phylogenetic analyses of the aligned dataset were performed with neighbor joining (NJ) and maximum likelihood (ML) analyses, also within the MEGA5 package. Based on the Bayesian information criterion of MEGA 5, Kimura 2-parameter model with gamma distribution $(\mathrm{K} 2+\mathrm{G})$ was selected for the NJ and ML analysis. The NJ and ML trees were obtained using the default settings with "partial deletion" for gaps/missing data treatment. A bootstrap analysis was conducted with 1000 replication. Xylaria hypoxylon was used as the outgroup. The sequences from our study were deposited in GenBank under the accession number KJ767718 for Cryptovalsa ampelina and KM245033 for Diatrypella iranensis.

Table 1 Isolates used in this study with the GenBank accession numbers of the ITS rDNA sequences *

\begin{tabular}{lll}
\hline Species & Strain no. & GenBank accession no. \\
\hline Cryptosphaeria ligniota (Fr.) Auersw. & C2C & AJ302418 \\
Cryptosphaeria pullmanensis Glawe & UCD2373NV & GQ293967 \\
Cryptosphaeria subcutanea (Wahlenb.) Rappaz & A56B & JQ781795 \\
Cryptovalsa ampelina (Nitschke) Fuckel & A001 & GQ293901 \\
Cryptovalsa ampelina (Nitschke) Fuckel & CBS 117485 & AY920391 \\
Cryptovalsa ampelina (Nitschke) Fuckel & KHJ20 & KJ767718 \\
Cryptovalsa rabenhorstii (Nitschke) Sacc. & WA08CB & HQ692619 \\
Diatrype bullata (Hoffm. : Fr.) Fr. & CBS 215.87 & AJ302422 \\
Diatrype disciformis (Hoffm. : Fr.) Fr. & D8M & AJ302437 \\
Diatrype prominens Cooke \&Harkn. & ATCC MYA-4410 & FJ430594 \\
Diatrype spilomea Syd. & D17C & AJ302433 \\
Diatrype stigma (Hoffm. : Fr.) Fr. & F-091,970 & AJ302435 \\
Diatrype undulata (Pers. : Fr.) Fr. & CBS 271.87 & AJ302436 \\
Diatrypella iranensis & KDQ18 & KM245033 \\
Diatrypella favacea (Fr.) Ces. \& De Not. & R191 & JN689955 \\
Diatrypella frostii Peck & ATCC 52484 & AJ302441 \\
Diatrypella prominens (Howe) Ellis \& Everh. & DL28A & AJ302442 \\
Diatrypella pulvinata Nitschke & DL29C & AJ302443 \\
Diatrypella quercina (Pers.) Cooke & DL30M & AJ302444 \\
Diatrypella verruciformis (Ehrh.: Fr.) Nitschke & UCROK856 & JX144788 \\
Diatrypella vulgaris Trouillas, W. M. Pitt \& Gubler & HVGRF03 & HQ692590 \\
Eutypa armeniacae Hansf. \& Carter & ATCC 28120 & DQ006948 \\
Eutypa consobrina (Mont.) Rappaz & CBS:122678 & EU552125 \\
Eutypa laevata (Nitschke) Sacc. & OHCS1 & KF453548 \\
Eutypa lata (Pers.) Tul. \& C. Tul. & GA4 & AY462563 \\
Eutypella caricae (De Not.) Berl. & ATCC 42768 & JX241652 \\
Xylaria hypoxylon (L.) Grev. & & AY327477 \\
\hline
\end{tabular}

*Sequences obtained in this study are given in bold. 


\section{Results}

\section{Molecular phylogeny}

Sequences of the ITS1-5.8S-ITS2 region were obtained by using primers ITS1 and ITS4 from the specimens of new species and Cryptovalsa ampelina. These sequences data were aligned together with sequences available in GenBank (Table 1). The final ITS dataset included 25 taxa and 726 positions, of which 282 were constant. Size of our sequences were $571 \mathrm{bp}$ for the new species and $543 \mathrm{bp}$ for Cryptovalsa ampelina. On the phylogenetic tree, the undescribed species was a sister taxon of Diatrypella quercina supported with high bootstrap value (Fig. 1).

The neighbor joining and maximum likelihood trees using the ITS region presented similar topologies, and only the neighbor joining tree is presented (Fig. 1). Diatrypella quercina and Diatrypella iranensis formed an individual clade with Diatrype species. Based on both morphology and molecular sequence data, the occurrence of Cryptovalsa ampelina in Iran was confirmed with $100 \%$ bootstrap values.

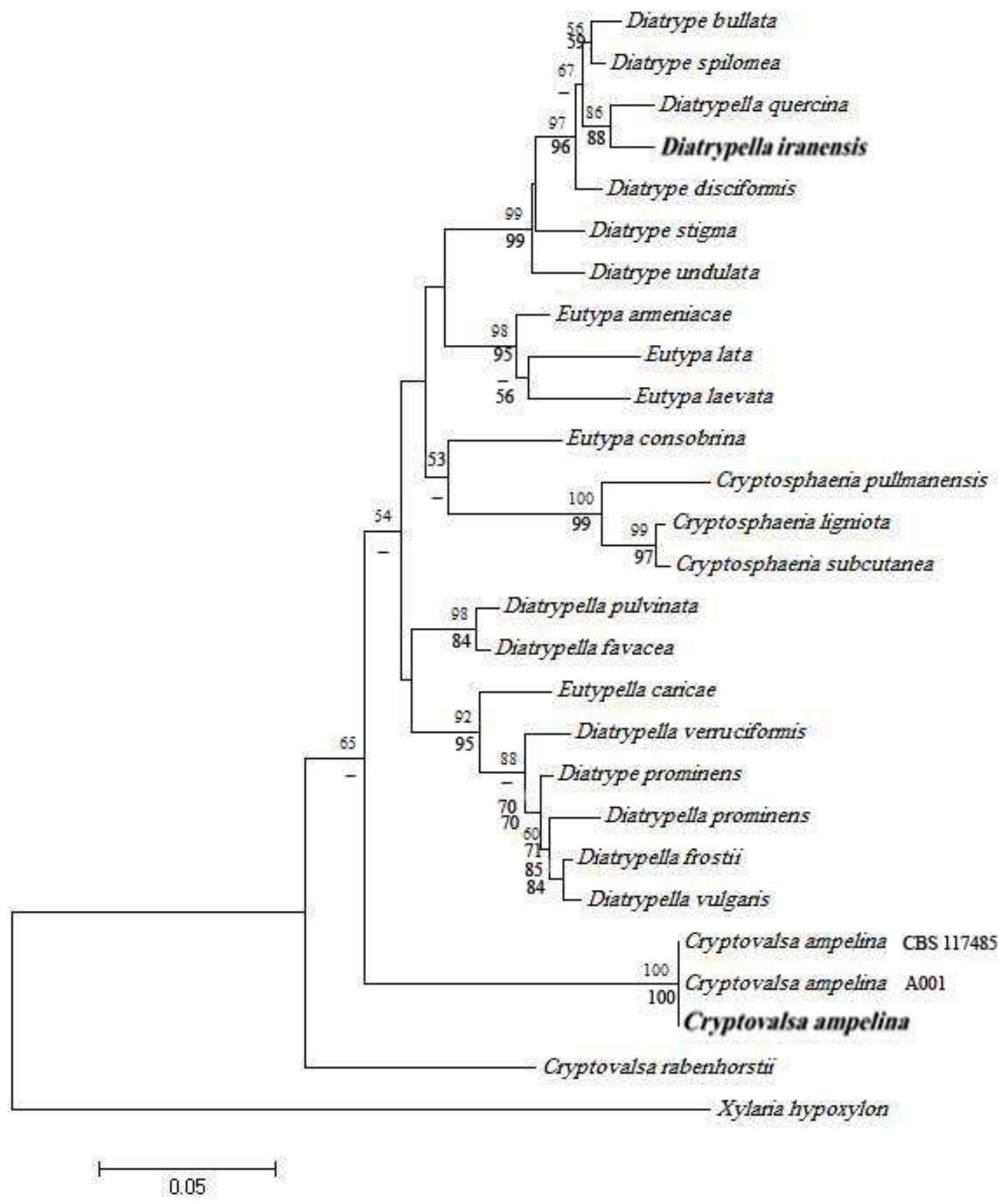

Fig. 1 - Phylogenetic tree for selected species of the Diatrypaceae obtained by neighbor joining analysis based on an alignment of ITS1-5.8S-ITS2 sequence data. Bootstrap values greater than $50 \%$ are indicated at the nodes. The new sequences obtained in this study are indicated in boldface. Bootstrap values (in \%) above branches are from the neighbor joining analysis (1000 bootstraps) and under branches from maximum likelihood analyses (1000 bootstraps). 


\section{Taxonomy}

Diatrypella iranensis Mehrabi \& Hemmati, sp. nov.

Figs 2-6

MycoBank MB 809719

Etymology - Refers to the country where the specimen was found.

Stromata immersed in the bark of dead branches ( $3 \mathrm{~mm}$ diameter), erumpent, circular to ovoid, surface black, finely rugose due to the ostioles of the perithecia, 2-5(2.9) $\mathrm{mm}$ diam, delimited by a black zone in the host tissues, with groups of 4-57 perithecia, arranged on a unique layer in the bark, circular to ovoid, 280-650 $\mu \mathrm{m}$ diam, ostioles dark brown, at the same level of the stroma surface or slightly above, 28-100 $\mu \mathrm{m}$ diam, perithecia dark brown, circinately arranged, crowded, globoid to subgloboid, surrounded by whitish yellow entostroma. Asci elongate, subcylindrical to clavate, long-stipitate, $(55-) 70-110(-130) \times 6-9(-10) \mu \mathrm{m}$, polyspored; Ascospores allantoids, subhyaline, yellowish in mass, aseptate, (5-)6-7(-8) $\times 1-1.3(-1.5) \mu \mathrm{m}$. Paraphyses elongate, filiform, septate. Colonies white on PDA, cottony, reverse of colonies pale yellow, covering $85 \mathrm{~mm}$ Petri dish after 8 days at $24^{\circ} \mathrm{C}$.

Anamorph on Quercus twig: Acervuli immersed in bark, 500-700 $\mu \mathrm{m}$ diam, flat to subconical, hymenium labyrinthiform, yellow to black, with golden yellow stratum of spores. Spores slender and strongly arcuate, $18-38(-45) \times 0.6-0.8 \mu \mathrm{m}$

Known distribution - Southwestern Iran

Type - Iran, Sisakht city, on dead branches of Quercus brantii Lindl., 9 April 2013, coll. M. Mehrabi, KDQ18 (Holotype, IRAN 16600 F) - Ex-type culture IRAN 2280 C.

ITS sequence - KM245033.

Notes - The genus Diatrypella is one of the largest genera of Diatrypaceae and is represented by about 33 species worldwide (Kirk et al. 2008). The delineation of the diatrypaceous genera is often problematic because the characters of the stromata are extremely variable within the same species (Vasilyeva and Stephenson, 2004). The presence of conical or truncate stromata, cushion-like or discoid, usually delimited by a black zone in host tissues, umbilicate or sulcate ostioles with polysporous asci assigned this fungus to the genus Diatrypella (Vasilyeva \& Stephenson 2005). The new species belongs to the genus Diatrypella based on the features mentioned above and resembles in many aspects earlier description of $D$. quercina and D. pulvinata (Croxall 1950, Glawe \& Rogers 1984). However, the spores of D. quercina are longer $(8-12 \times 2-3$ $\mu \mathrm{m}$ vs. 6-7 $\times 1-1.3 \mu \mathrm{m}$ ) (Croxall, 1950) than those of the new species, . In addition, D. quercina differs from the new species by marked curvature of the ascospores and wider asci, with sporiferous parts of $64-160 \times 8-12 \mu \mathrm{m}$. The new species also differs from $D$. pulvinata (Glawe \& Rogers 1984) on the basis of stromatal morphology and ascus size. Despite resemblance in stroma morphology, Diatrypella iranensis could be clearly distinguished from $D$. favacea because of the unique 6-sulcate ostioles of this last species (Croxall 1950, Vasilyeva \& Stephenson 2005).

Sequence data of the ITS region confirm the position of Diatrypella iranensis within the genus Diatrypella (Fig. 1). Also, phylogentic analysis of the ITS data set showed that D. iranensis formed a unique lineage that differed from all Diatrypella species included in the study. In the ITS analysis, $D$. iranensis and $D$. quercina were shown to be sister species, which was supported by moderate bootstrap value ( $86 \%$ in NJ, $88 \%$ in ML, Fig.1). D. iranensis and D. quercina also grouped with other Diatrype spp. including D. bullata, D.disciformis and D. spilomea. Previous studies have suggested that Diatrypella is the polysporous counterpart of Diatrype (Vasilyeva \& Stephenson 2005) and the multisporate asci character may have appeared several times during the evolution of the family (Acero et al. 2004). Molecular phylogenetic studies that include more representative taxa and more gene regions may help better resolve such taxonomic relationships.

Cryptovalsa ampelina (Nitschke) Fuckel, Symbolae Mycologicae, p 212. 1870.

Figs $7-11$

Basionym: Valsa ampelina Nitschke, Pyrenomycetes Germanici 1, p. 156, 1867.

On dead branches $0.5 \mathrm{~mm}$ diameter. Stromata immersed in bark, poorly developed, dotted at the surface with visible black zone on the bark surface, circular to ovoid, 0.3-1.5(0.5) $\mathrm{mm}$ diam, 

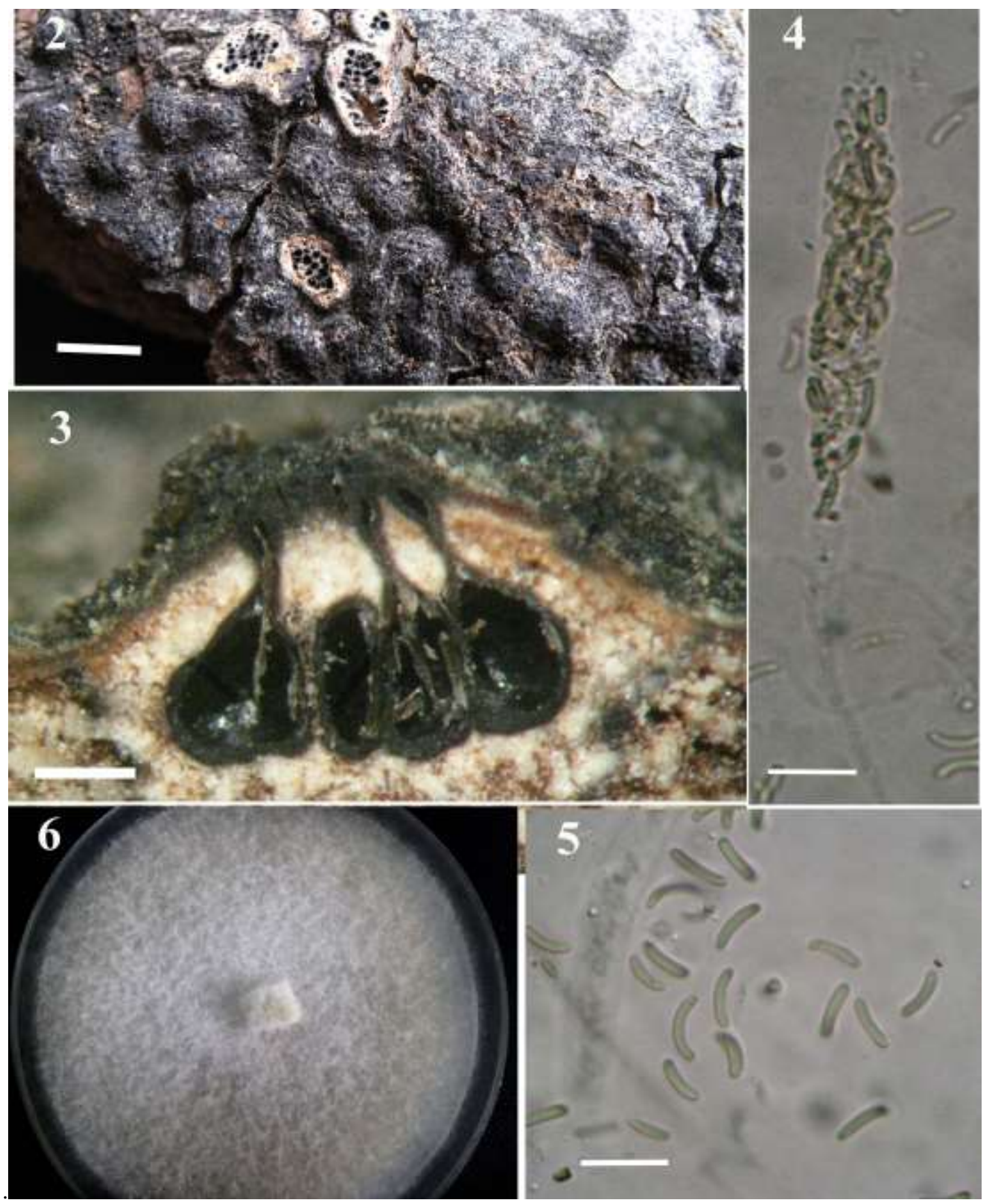

Figs 2-6 - Morphology of Diatrypella iranensis from Quercus brantii. 2 Habit of ascostromata on bark. 3 Longitudinal section through the stroma shows ostioles and perithecia surrounded in whitish yellow entostroma and ascoma delimited by black zone. 4 Ascus with ascocpores. 5 Allantoids ascospores. 6 Colony morphology on PDA. - Bars $2=5 \mathrm{~mm} .3=500 \mu \mathrm{m} .4,5=10 \mu \mathrm{m}$.

containing 1-6 perithecia arranged at different depth in the bark, 280-630 $\mu \mathrm{m}$ diam, delimited by distinct black zone, discs dark brown to gray, 0.1-0.3 $\mathrm{mm}$ diam, ostioles at the same level as the discs or slightly above, dark brown, 28-70 $\mu \mathrm{m}$ diam, perithecia dark brown, circinately arranged, globoid to subgloboid, surrounded by yellow to grey entostroma. Asci elongate, subcylindrical to clavate, long-stipitate, (60-)80-120(-140) $\times 6-9(-10) \mu \mathrm{m}$, polyspored; Ascospores allantoid, rounded at the apex, subhyaline to yellowish brown, aseptate, $(6-) 8-10(-12) \times 1.8-3 \mu \mathrm{m}$. Paraphyses absent. Colonies white on PDA, cottony, with diffuse margins, covering $85 \mathrm{~mm}$ Petri dish after 7 days at $24^{\circ} \mathrm{C}$, reverse later (>20 days) turning dark, beginning from the center of the colony. 

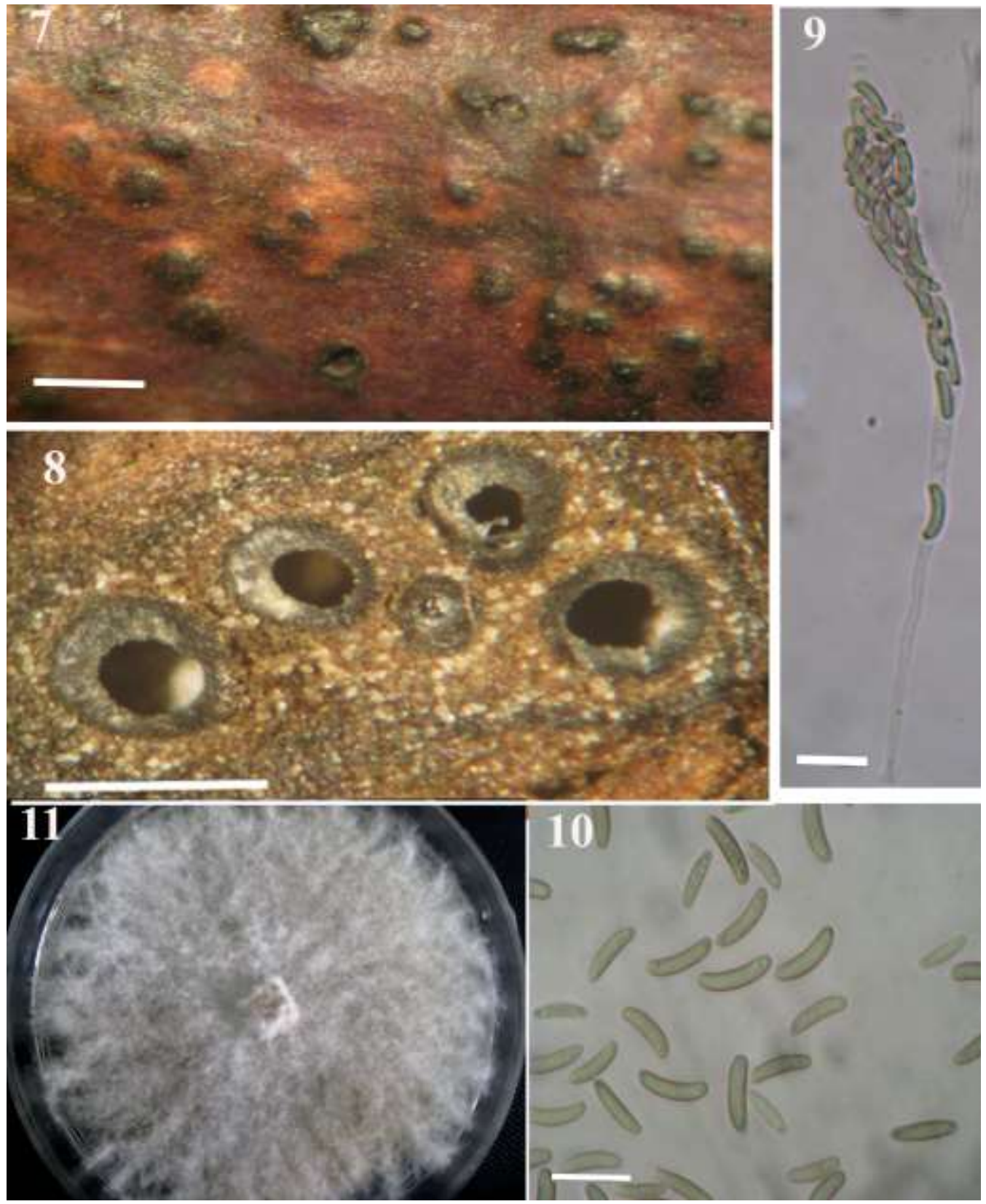

Figs 7-11 - Morphology of Cryptovalsa ampelina from Juglans regia. 7 Habit of ascostromata on bark with visible black zone on the bark surface. 8 Transverse section through the ascoma shows globose perithecia surrounded in entostroma and ascoma delimited by black zone. 9 Ascus with ascocpores. 10 Allantoid ascospores. 11 Colony morphology on PDA. - Bars $7=1 \mathrm{~mm} .8=500$ $\mu \mathrm{m} .9,10=10 \mu \mathrm{m}$.

Specimen examined - Iran, Kermanshah provinces, Paveh city, on dead branches of Juglans regia L., 13 May 2013, M. Mehrabi, KHJ20(IRAN 16599 F, IRAN 2281 C).

Notes - This species is morphologically typical members of the genus Cryptovalsa (poorly developed stroma, polysporous asci) and resembles closely with $C$. ampelina (Trouillas et al. 2010a). However, this fungus has a visible black zone on the bark surface that surrounded the globose perithecia inner the host tissue, and also asci are narrower in width. The genus Cryptovalsa is similar to Cryptosphaeria in stromal morphology (poorly developed) but differs from it by its polysporous asci. This species previously was reported from Juglans regia in California, and its pathogenicity to grapevine has been confirmed (Trouillas et al. 2010a, Trouillas \& Gubler 2010), although some authors suggested a low virulence (Luque et al. 2006, Mostert et al. 2004). The present record is the first report of this species in Iran. 


\section{Acknowledgments}

The authors wish to acknowledge Research Institute of Modern Biological Techniques (University of Zanjan) for the use of their equipments.

\section{References}

Acero FJ, González V, Sánchez-Ballesteros J, Rubio V, Checa J, Bills GF, Salazar O, Platas G, Peláez F. 2004 - Molecular phylogenetic studies on the Diatrypaceae based on rDNA-ITS sequences. Mycologia 96, 249-259.

Carmarán CC, Pildain MB, Vasilyeva LN. 2009 - The family Diatrypaceae (Ascomycota) in Argentina: new species and new records. Nova Hedwigia 88, 521-530.

Carter MV. 1991 - The status of Eutypa lata as a pathogen. Monograph, Phytopathological Paper No 32. Commonwealth Agricultural Bureau, International Mycological Institute, UK.

Catal M, Jordan SA, Butterworth SC, Shilder AMC. 2007 - Detection of Eutypa lata and Eutypella vitis in grapevine by nested multiplex polymerase chain reaction. Phytopathology 97, 737747.

Croxall HE. 1950 - Studies on british pyrenomycetes III. The British species of the genus Diatrypella Cesati and deNotaris. Transactions of the British Mycological Society 33, 4572.

Chacón S, Dörge D, Weisenborn J, Piepenbring M. 2013 - A new species and a new record of Diatrypaceae from Panama. Mycologia 105, 681-688.

Davidson RW, Lorenz RC. 1938 - Species of Eutypella and Schizoxylon associated with cankers of maple. Phytopathology 28, 733-745.

Ershad D. 2009 - Fungi of Iran, 3th edition. Tehran, Iran: Agricultural Research, Education and Extension Organization. 531 p.

Glawe DA, Rogers JD. 1984 - Diatrypaceae in the Pacific Northwest. Mycotaxon 20, 401-460.

Grassi E, Pildain MB, Levin L, Carmaran C. 2014 - Studies in Diatrypaceae: the new species Eutypa microasca and investigation of ligninolytic enzyme production. Sydowia 66 (1): 99114.

Hinds TE. 1981 - Cryptosphaeria canker and Libertella decay of aspen. Phytopathology 71, 11371145.

Jordan SA, Schilder AMC. 2007 - Characterization of Eutypella vitis, a potential pathogen of grapevines. Phytopathologia Mediterranea 46, 105.

Kirk PM, Cannon PF, Minter DW, Stalpers JA. 2008 - Ainsworth and Bisby's Dictionary of the Fungi, 10th edn. CAB International, Wallingford.

Liu D, Coloe S, Baird R, Pedersen J. 2000 - Rapid mini-preparation of fungal DNA for PCR. Journal of Clinical Microbiology 38, 471.

Luque J, Sierra D, Torres E, Garcia F. 2006 - Cryptovalsa ampelina on grapevines in N.E. Spain: identification and pathogenicity. Phytopathologia Mediterranea 45, S101-S109.

Martín MT, Martín L, de-Francisco MT, Cobos R. 2009 - First report of Lasidiplodia theobromae and Cryptovalsa ampelina associated with grapevine decline from Castilla y Leon, Spain. Plant Disease 93, 545.

Mehrabi M, Hemmati R. 2013 - First report of the genus Libertella in Iran. Iranian Journal of Plant Pathology 49, 357-358.

Mostert L, Halleen F, Creaser ML, Crous PW. 2004 - Cryptovalsa ampelina, a forgotten shoot and cane pathogen of grapevines. Australas Plant Pathology 33, 295-299.

Rappaz F. 1987 - Taxonomie et nomenclature des Diatrypacées à asques octosporées. Mycologia Helvetica 2, 285-648.

Romero AI, Carmarán CC. 2003 - First contribution to the study of Cryptosphaeria from Argentina. Fungal Diversity 12, 161-167. 
Stewart JE, Kim MS, James RL, Dumroese RK, Klopfenstein NB. 2006 - Molecular characterization of Fusarium oxysporum and Fusarium commune isolates from a conifer nursery. Phytopathology 96, 1124-1133.

Tamura K, Peterson D, Peterson N, Stecher G, Nei M, Kumar S. 2011 - MEGA5: molecular evolutionary genetics analysis using maximum likelihood, evolutionary distance and maximum parsimony methods. Molecular Biology and Evolution 28, 2731- 2739.

Thompson JD, Higgins DG, Gibson TJ. 1994 - Clustal W: improving the sensitivity of progressive multiple sequence alignment through sequence weighting, position- specific gap penalties and weight matrix choice. Nucleic Acids Research 22, 4673-4680.

Tiffany LH, Gilman JC. 1965 - Iowa Ascomycetes IV, Diatrypaceae. Iowa State College Journal of Science 40, 121-161.

Trouillas FP, Gubler WD. 2004 - Identification and characterization of Eutypa leptoplaca, a new pathogen of grapevine in Northern California. Mycological Research 108, 1195-1204.

Trouillas FP, Gubler WD. 2010 - Pathogenicity of Diatrypaceae species in grapevines in California. Plant Disease 94, 867-872.

Trouillas FP, Úrbez-Torres JR, Gubler. WD. 2010a - Diversity of diatrypaceous fungi associated with grapevine canker diseases in California. Mycologia 102, 319-336.

Trouillas FP, Sosnowski MR, Gubler WD. 2010b - Two new species of Diatrypaceae from coastal wattle in Coorong National Park, South Australia. Mycosphere 1(2), 183-188.

Trouillas FP, Wayne MP, Sosnowski MR, Huang R, Peduto F, Loshiavo A, Savocchia S, Scott E.S, Gubler WD. 2011 - Taxonomy and DNA phylogeny of Diatrypaceae associated with Vitis vinifera and other woody plants in Australia. Fungal Diversity 49, 203-223.

Úrbez -Torres JR, Peduto F, Striegler RK, Urrea-Romero KE, Rupe JC, Cartwright RD, Gubler WD. 2011 - Characterization of fungal pathogens associated with grapevine trunk diseases in Arkansas and Missouri. Fungal diversity doi: 10.1007/s13225-011-0110-4.

Úrbez-Torres JR, Adams P, Kama J, Gubler WD. 2009 - Identification, incidence and pathogenicity of fungal species associated with grapevine dieback in Texas. American Journal of Enology and Viticulture 60(4), 497-507.

Vasilyeva LN, Ma H. 2014 - Diatrypaceous fungi in north-eastern China. 1. Cryptosphaeria and Diatrype. Phytotaxa 186(5), 261-270.

Vasilyeva LN, Stephenson SL. 2004 - Pyrenomycetes of the Great Smoky Mountains National Park. I. Diatrype Fr. (Diatrypaceae). Fungal Diversity 17, 191-201.

Vasilyeva LN, Stephenson SL. 2005 - Pyrenomycetes of the Great Smoky Mountains National Park. II. Diatrypella (Ces. et De Not.) Nitschke and Cryptovalsa Ces et De Not. (Diatrypaceae). Fungal Diversity 19, 189-200.

Vasilyeva LN, Stephenson SL. 2006 - Pyrenomycetes of the Great Smoky Mountains National Park. III. Cryptosphaeria Ces. et De Not., Eutypa Tul. et C. Tul., and Eutypella (Nitschke) Sacc. (Diatrypaceae). Fungal Diversity 22, 243-254.

Vasilyeva LN, Stephenson SL. 2009 - The genus Diatrype (Ascomycota, Diatrypaceae) in Arkansas and Texas (USA). Mycotaxon 107, 307-313.

White TJ, Bruns T, Lee S, Taylor J. 1990 - Amplification and direct sequencing of fungal ribosomal RNA genes for phylogenetics. In: PCR Protocols, a Guide to Methods and Applications (eds. MA Innis, DH Gelfand, JJ Sninsky and J White) Academic Press. San Diego, Ca, USA, 315-322. 